\title{
Identifying the Internal Factors and Challenges in Branding of Iran Basketball League
}

\author{
${ }^{1}$ Zohre Rezaei ${ }^{*}$, ${ }^{2}$ Seyed Nasrollah Sajjadi, ${ }^{3}$ Alireza Elahi, ${ }^{1}$ Mehdi Rasooli \\ ${ }^{1}$ Sport Management Department, Sport Sciences Research Institute of Iran, Tehran, Iran. ${ }^{2}$ Department \\ of Sport Management, Faculty of Sport Sciences, University of Tehran, Tehran, Iran. ${ }^{3}$ Department of \\ Sport Management, Faculty of Sport Sciences, Kharazmi University, Tehran, Iran.
}

Submitted 01 September 2018; Accepted in final form 17 December 2018.

\begin{abstract}
Background. The clubs of the premier league and the basketball federation need to attract and retain fans and sponsors in order to earn financial revenues, through the proper model of branding, to be of interest to the media and customers. Objectives. Thus, the purpose of this study was to identify the internal factors and challenges in the branding of the Iranian basketball league. Methods. This research based on purpose is practical and based on field research is a qualitative research type. The statistical population of this study consisted of knowledgeable experts in the field of brand and basketball sport. Based on snowball sampling method, to the extent of reaching the theoretical saturation, 19 individuals were selected as a statistical sample. In this study, the data collection tool was a qualitative interview. Grounded theory was used to collect and analyze data. Results. Totally 89 tokens were identified in the open source coding process, that in the first stage, coding was classified into 11 classes in terms of subject and concept closeness. Also, results showed that the factors and challenges of the branding in Iranian Basketball League were three main factors, such as the philosophy and nature of basketball and the nature of sport. Conclusion. Based on our results, identification of the internal branding factors and challenges of the Iranian Basketball League was recognized and the proposed model was presented based on identified cases at three levels of operational, intermediate and strategic.
\end{abstract}

\section{KEY WORDS: Branding, Basketball, Grounded Theory.}

\section{INTRODUCTION}

Considering competitive conditions and constant environmental changes, sports industry and related organizations have realized that every customer requires specific conditions. Therefore, like the past, they are not facing a growing economic system and markets, and, in this condition, they should manage the situation to gain a higher market share. Nowadays, marketing is the discovery of a need and efforts to meet that need $(1,2)$. Focusing on branding is a strategic imperative given changing circumstances and competitive markets. The sport organizations and clubs should also use this strategy to attract more fans (2). Meanwhile, branding is an internal emotional feeling of a person about a product, service, or organization, and is the largest intangible asset of the companies and the basis of competitive advantage (3). Branding is important because of consumer protection, stimulation of performance, creation of a competitive economy, and expansion of geographical boundaries (4).

In today businesses, branding and identification of factors and challenges in its

*. Corresponding Author:

Zohre Rezaei, PhD

Department of Sport Management, Sport Sciences Research Institute of Iran, $5^{\text {th }}$ Alley, Miremad St., Motahari St.,Tehran, Iran.

E-mail: rezaei_zohree@yahoo.com 
path are important indicators leading to improved marketing and economics (5). Branding is one of the most important intangible assets of any organization which has attracted their attention over the last few decades. Design and manufacture of powerful brands are among the top priorities of successful organizations, as, according to the public belief, successful brands have the potential to create advantage attracting the attention of all participants especially sports organizations (6). Sports clubs and leagues, federations, as well as national and international Olympic and Paralympic Committees are the organizations that operate in a complex and competitive environment. They need to create a strong image in the minds of their customers to recruit volunteers, attract sponsors and gifts, and develop loyalty among their fans. Their brand value depends on creating a strong, desirable, and unique image (5).

Nowadays, successful presence of brands inspires a sense of purposefulness and commitment in the society, in addition to dominating markets, strengthening a sense of trust and loyalty in customers and creating value for the shareholders. By innovation, the brands improve the name of a country and its popularity in the business world $(7,8)$. Basketball has been struggling with many problems despite the long history of its formation (since 1931) and a history of several Asian Games and Olympic Games. Absence of outstanding teams due to financial difficulties in the Basketball League confirms that the Iranian Basketball League has not used all its potentials over the past few years. Identification of factors and challenges faced by the Basketball League is a very significant topic which has been dealt with in this study. Identifying internal and external factors, and finally, branding, can properly address financial problems such as attracting financial support, privatization, return on investment, and value creation. The reasons for conducting this study include the changing situation of the basketball federation, changes in strategic basketball league programs, lack of stability in the management departments of the organization, lack of a clear pattern for the organization performance, lack of financial benefits, and lack of attraction for sponsors (9).

Considering the importance of internal factors and the possibility of reducing inhibitors and strengthening facilitators in the organization's internal environment, as well as, lack of comprehensive research in this field in the sports industry, especially, in the field of basketball, this study aimed at identifying the internal factors and challenges ahead of branding of Iranian Basketball League. The results can be used by individuals and institutions including the Basketball League, clubs in the League, Basketball Federation, League sponsors, investors, etc.

Identification of internal branding factors and challenges in the Basketball League will lead to recognition of this league, attraction of higher investment, willingness of better teams to attend the league, presence of more powerful foreign players, greater media coverage, loyal fans, and ultimately, higher income for the league and Basketball Federation. Failure to take advantage of these and especially, in an emerging field, such as basketball, will cause organizations to face several problems, most notably, weakened cultural and political relations, inability to maintain competitive conditions, lack of audience satisfaction, failure in emotional relationships, and lack of full support from the organization, losing loyal supporters, and lack of financial benefits (10).

\section{MATERIALS AND METHODS}

Research Methodology. It was an applied survey study. Grounded theory was used due to the unknown nature of the subject, existence of very different processes, existence of unknown variables, and lack of quantitative studies. Interviews, documentation, observations, etc. were used to collect data.

Procedure. The research stages included: 1 . Selecting participants, 2. Collecting data, 3. Regularizing data, 4. Analyzing data, and 5. establishing the theory $(11,12,13)$.

Participants and instrument: Due to the nature of research and not identifying the number of samples, snowball and purposeful samplings were used to attain theoretical saturation. A semistructured questionnaire was used to collect data.

Note that due to the analytical nature of the research method and the emergence of new cases during the research process, some experts were interviewed more than once for confirmation or refusal of the details (Table 1).

Finally, the extracted model was investigated by four experts and finalized. Qualitative interviews with university elites and scholars 
were used for data extraction. During the interview, various recording methods such as note taking and recording of the interview on the audio or video tape were used and, after completing the interview, detailed notes about the interview process were taken.

Analysis and Processing Steps. In the analysis section, the relevant data were recorded and analyzed based on the following steps:

Step 1: Reviewing the literature, Step 2: Selecting cases or samples, Step 3: Developing a data collection framework (initial formation by the researcher and approval by other members of the research team); Step 4: Entering the research field (conducting interviews with the time and place proposed by the interviewees), Step 5: Setting up the data (setting the interview notes for data coding), Step 6: Analyzing the first case data (coding, data analysis, and new organization of concepts), Step 7: Repeating theoretical sampling (flexible sampling along the research path), Step 8: Achieving saturation (comprehensive concepts and repetitive interviews), and Step 9: Examining the literature (review of fundamental research on the path to create a model) (10).

Data analysis was performed in three stages: open coding, axial coding, and selective coding. The data analysis process begins with open coding and identification of the concepts. In the axial coding step, the data that are broken into the coding step are merged. Finally, in the selective coding, the body of research is formed. In this study, the theory was developed by analyzing the relationships between concepts as well as comparing with other existing models. The theory was also reviewed by experts and was finally confirmed.

Table 1. Details of research interviews

\begin{tabular}{lccc}
\hline \multicolumn{1}{c}{$\begin{array}{c}\text { Number } \\
\text { Group }\end{array}$} & $\begin{array}{c}\text { Number of people } \\
\text { not interviewed }\end{array}$ & $\begin{array}{c}\text { Number of } \\
\text { interviews }\end{array}$ & $\begin{array}{c}\text { Number of people } \\
\text { that approved } \\
\text { model }\end{array}$ \\
\hline $\begin{array}{l}\text { Managers and executive specialists and marketing } \\
\text { managers of the Premier League Basketball }\end{array}$ & 2 & 5 & 1 \\
\hline Economists, especially brand experts & 1 & 1 & 0 \\
\hline $\begin{array}{l}\text { experts and faculty members that specializing in } \\
\text { sports marketing and brand management }\end{array}$ & 3 & 5 & 1 \\
\hline $\begin{array}{l}\text { Individuals with the sports history in Basketball } \\
\text { League (Coaches and Basketball Premier League } \\
\text { players) }\end{array}$ & 2 & 4 & 0 \\
\hline $\begin{array}{l}\text { Other people that aware the subject matter of the } \\
\text { research according to the nature of qualitative } \\
\text { research and position }\end{array}$ & 1 & 19 & 4 \\
\hline Total & 9 & & \\
\hline
\end{tabular}

\section{RESULTS}

After creating the open codes, they were reviewed and modified by three experts. Then, the theoretically related concepts were grouped under a code adopting a new name. In the open coding, 89 concepts were identified and at the axial coding stage, 11 sub-categories were obtained. Finally, the axial coding process focusing on the factors and challenges in branding Iran Basketball League was conducted according to Shilhang's (2008) sports brand management model and Strasuss and Corbin $(2003,2008)$ theories. Here, three main concepts of conditions were obtained: Iranian basketball league (8 sub categories and 75 initial codes), philosophy and nature of basketball (2 sub categories and 10 initial codes), and nature of sport ( 1 sub category and 4 initial codes $)(13,11$, 12). Their details are presented in the Table 2.

After confirming the factors derived from the interviews and coding them, the internal factors and challenges of the Iranian Basketball League were identified in three general areas: The Iranian basketball league, the philosophy and nature of the Iranian basketball, and the nature of sport. They are represented in the Figure 1.

Eventually, the information was reviewed by the research team. After final confirmation of the extracted factor, the final model was plotted according to the open coding, sub categories, general category, and axial code further was confirmed by the experts (Figure 2). 
Table 2. Coding Internal Factors and Challenges of Branding Iran Basketball League

\begin{tabular}{|c|c|c|c|}
\hline Main Code & General Category & Special Category & Concepts (Basic Codes) \\
\hline \multirow{6}{*}{$\begin{array}{c}\text { Internal } \\
\text { Environment }\end{array}$} & \multirow{6}{*}{$\begin{array}{l}\text { Conditions of } \\
\text { Iranian Basketball } \\
\text { League }\end{array}$} & Basketball League & $\begin{array}{l}\text { 1. League instability conditions** } \\
\text { 2. Unstable events outside the league } \\
\text { 3. Weakly conditions of league holding } * * \\
\text { 4. Negative effects of short league time ( } 5 \text { months per year) } \\
\text { 5. Lack of electronic leagues } \\
\text { 6. Instability of league planning } \\
\text { 7. Limited and variable teams in the Premier League } \\
\text { 8. Qualitative difference of the league inside with outside } \\
\text { leagues } \\
\text { 9. Not having a competitive balance in the Basketball Premier } \\
\text { League } \\
\text { 10. Results and quality level of national team and its influence on } \\
\text { the league*** } \\
\text { 11. Pay attention to the league(as a system) and the sub-systems } \\
\text { 12. paying attention to the lower league (except to national team } \\
\text { and Premier League) } \\
\text { 13. Disadvantages of industrial and technical teams diversity } \\
\text { 14. Involved in a small number of provinces (4 provinces) } \\
\text { 15. Differences between private and government teams } \\
\text { 16. possibility of using basketball enterprises } \\
\text { 17. Struggle and distance from basketball } \\
\text { 18. The need for proper and long-term goal setting in basketball } \\
\text { 19. Escape or extrication (Avoiding the Challenges of Life) } \\
\text { 20. Advantage of separation from community frameworks } \\
\text { 21. Desirable quality of judgment and execution factors** } \\
\text { 22. clashes with margins }\end{array}$ \\
\hline & & $\begin{array}{c}\text { Facilities } \\
\text { Management }\end{array}$ & $\begin{array}{l}\text { 1.inadequate Physical environment, facilities, equipment and } \\
\text { facilities } * * * * * * * * * \\
\text { 2. Poor physical facilities such as training Academy or Sports } \\
\text { Medicine Academy * } \\
\text { 3. Not having private stadiums in clubs } \\
\text { 4. Inappropriate conditions for the national team camp and } \\
\text { separate women's camp } \\
\text { 5. Facilities and assets of federation and league organization }\end{array}$ \\
\hline & & $\begin{array}{c}\text { Planning } \\
\text { Management }\end{array}$ & $\begin{array}{l}\text { 1.Have an operational plan in line with the strategic plan } \\
\text { 2. Take advantage of the strategic promotion of the league and } \\
\text { brand** } \\
\text { 3. Not having a plan to attract the audience } \\
\text { 4. Proper league planning (Federation Committee or Federation } \\
\text { Council)** } \\
\text { 5. Advantages of using the FIBA Calendar } \\
\text { 6. Gap between the decision makers and other people } \\
\text { 7. Planning to create event charm } \\
\text { 8. Management of shopping pleasure while watching the game }\end{array}$ \\
\hline & & $\begin{array}{c}\text { Financial } \\
\text { Management }\end{array}$ & $\begin{array}{l}\text { 1.Transparent financial management in financial matters } \\
\text { 2. Improper management of debt and fines } \\
\text { 3. Improper management of income sources such as shirt sales } \\
\text { 4. Proper management and clarity of contracts } \\
\text { 5. Crude retail of tournaments } \\
\end{array}$ \\
\hline & & $\begin{array}{l}\text { Management of } \\
\text { Legal and } \\
\text { International } \\
\text { Affairs }\end{array}$ & $\begin{array}{l}\text { 1.need to create a law with an executive guarantee } * * * * * * \\
\text { Non-use of rules and supervision of international basketball } \\
\text { organizations } \\
\text { Weak legal system(Not having the inspection board)**** } \\
\text { Weaknesses of the statute, regulations and law }\end{array}$ \\
\hline & & Players & $\begin{array}{l}\text { 1.Super star players or celebrity******* } \\
\text { Enter and maintain foreign player and coach } * * \\
\text { Attempts to enhance the player's reputation and behavior } \\
\text { Behavior management and personality of coaches and players } \\
\text { Transnational morale of basketball players } \\
\text { Paying attention to the views of the players } \\
\text { Pay attention to physical factors in foreign players such as height } \\
\text { and skin color } \\
\text { need to make players that feel secure about the club } \\
\text { need to pay attention to external patterns of attracting foreign } \\
\text { players } \\
\text { Product approved by player } \\
\text { level of bias and attachment of the player and coach to the club * } \\
\text { Technical, ethical and social performance of players } \\
\text { Social activities of the organizations and basketball players }\end{array}$ \\
\hline
\end{tabular}




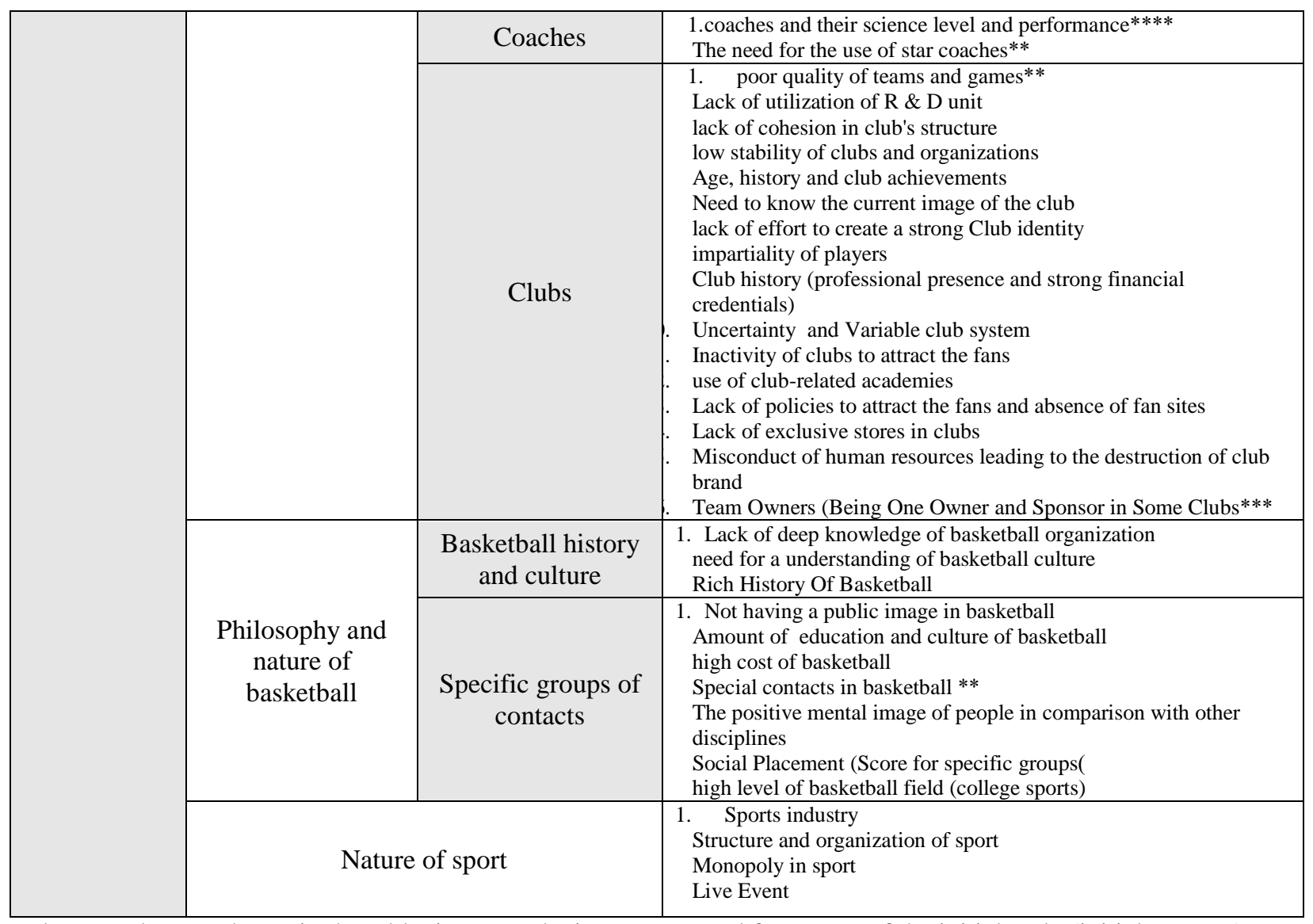

The stars that are shown in the table, it means the importance and frequency of the initial code (initial concept).

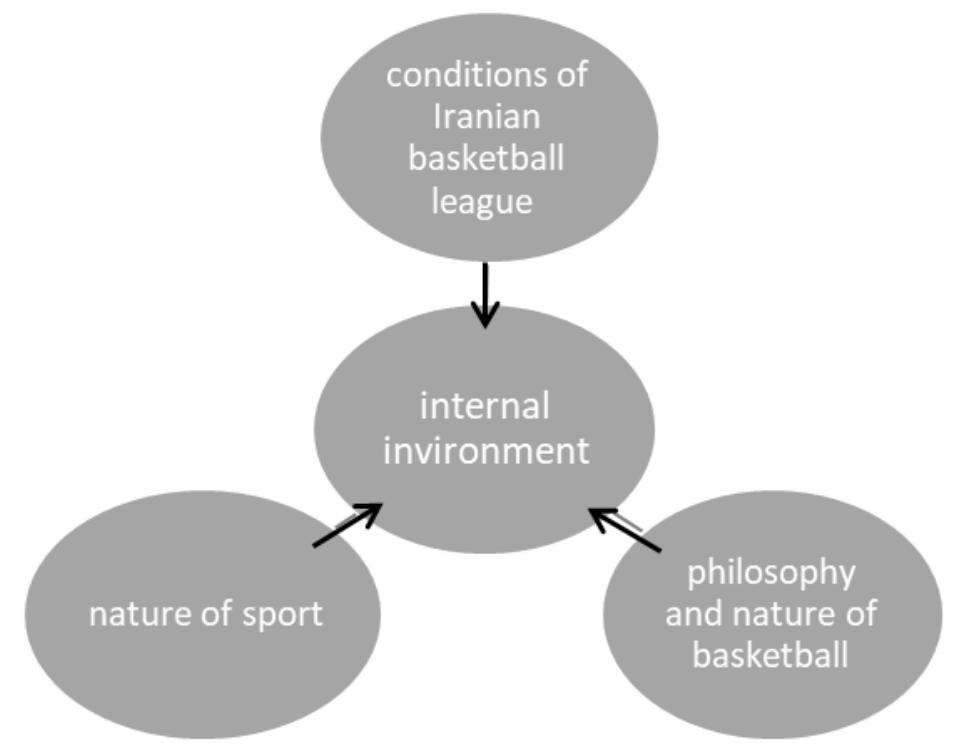

Figure 1. General Factors and Challenges of the Basketball League Branding 


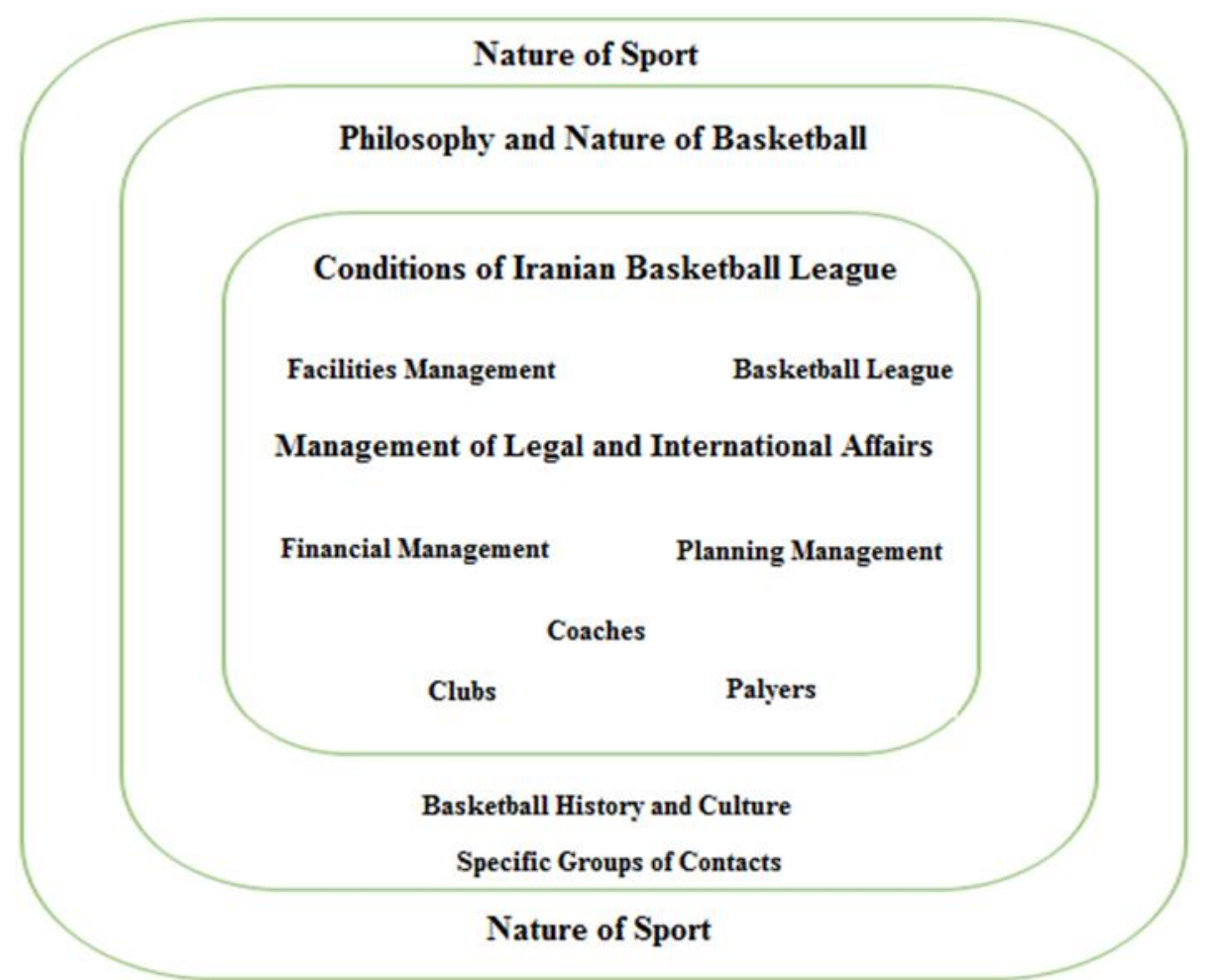

Figure 2. The Final Model of the Internal Factors and Challenges of Branding of the Iranian Basketball League

Accordingly, the Iranian Basketball League must become aware of its internal status to become a credible brand and use facilitators and control inhibitors. This stage involves understanding conditions of the league, the philosophy and nature of basketball, and the nature of sport. If the knowledge, control, and proper use of branding factors and challenges happen accurately, the Iranian Basketball League can become a credible brand. In an effort to create a satisfactory image and with continuous assessment, the Iranian Basketball League can consolidate its brand and become a mega-brand in the sports industry.

\section{DISCUSSION}

Considering the today's changing circumstances and competitive markets, branding is a strategic imperative necessitating sporting organizations and clubs to use this strategy to maintain and attract fans. As long as the internal factors and challenges of an organization are identified and managed, the brand cannot be cared for and upgraded. Considering the above and the importance of branding, this study aimed at identifying the factors and challenges of internal branding in the Basketball League of Iran. Totally, 89 tokens were identified in the open coding process which were categorized in 11 categories based on the concepts. These categories include the Basketball League, facility management, planning management, financial management, legal and international affairs management, players, coaches, clubs, basketball rich history and culture, basketball specific audience, and the nature of sport. In the axial coding process, the "internal challenges and factors of branding of the Iranian Basketball League" was considered as the axial phenomenon, the categories emerged in the final model, and general categories were described. Furthermore, the results revealed that three factors affected the branding pattern of the Iranian Basketball League: the Iranian basketball league conditions, the philosophy and nature of basketball, and the nature of sports. In the following, we tried to compare the findings of this study with the existing scientific and proven models and the results of other experiments. At the end, practical and conclusive suggestions are provided.

The conditions of the Iranian basketball league: In the development of sport, especially 
professional sport, some issues affect the situation in the basketball league. This can also affect other areas of sport. A study noted that facilities in any field of sport can be affected by financial issues. Al-Salih and Hartman (2013) suggested that the availability of appropriate facilities in sport leads to proper conditions and infrastructure for brand use (11).

Further, Tilman and Lijmbach (2012) argued that the nature of sport and various issues including related events are issues representing the need for development and attention to brand management (15). Cheng (2014) stated that use of players and coaches in sport makes it possible to perfectly chart the brand improvement. They pointed that players and coaches can make a difference in their brand value to complete brand management and achieve high goals. Creating business activities in the sport and using players and coaches' capabilities will increase attraction of customers in these business activities and improve brand management. Meanwhile, players and coaches can lead to the development of customer-related issues and strategies (17). Players and coaches, as the main pillars of Iran basketball league, can promote the brand growth and improvement in the Iran's Basketball League using the potential of the media. High popularity of some players and coaches in this sport has made it possible to attract fans to this sport. Benefitting from this potential of players and coaches can lead to brand promotion in the Iran Basketball League $(16,17)$.

The Iran Basketball League needs branding because of its potential. The various qualities and conditions existing in this league have made it possible to develop the sport by designing the branding model in the Iranian Basketball League. Further, managerial resources in this field including senior executives as well as old athletes, who play an important role in the development of this sport as pioneers, have created appropriate managerial approaches in this sport and provided proper conditions for brand development in Iran Basketball League. Consequently, the concepts affecting Iranian Basketball League branding including the Basketball League, facility management, planning management, financial management, legal and international management, players, coaches and clubs, have improved the competitive advantage of this league as well as development and necessity of designing and implementing a brand model in the Iranian Basketball League. Therefore, use of potentials created by the basketball League conditions has led to a greater hope of branding in the league, and which can also address the shortcomings in the league conditions such as the lack of specific spaces and weaknesses in legal actions $(10,15)$.

Philosophy and Nature of Basketball in Iran: The basketball has a high capacity, long history, and specific audience in Iran and has the potential to expand dimensions of marketing. This concept has been investigated by some researchers. In this regard, although it has not been able to affect all groups and individuals like football, researchers have argued that basketball has become a popular sport worldwide and has managed to progress in the branding field. The proper dynamics of the Iranian Basketball League as well as acquisition of some international successes in basketball in recent years has led it to play a significant role in brand development. In the meantime, a large number of fans in Iran including the young and educated group, have contributed to emergence of the nature of basketball as an effective field of branding.

The large number of fans in this sport has contributed to branding given the very nature of basketball and its events at both national and international levels. Although basketball influence is lower compared to some sports, including football, in national and international arenas, its rich history and culture and its specific audience have provided a basis for its impact on Iran sports industry (20-25).

The nature of sport: the nature of sport and importance of sporting events have augmented the significance of branding in the sports industry which has been ignored in research. Rasooli (2014) maintained that sport has become a popular industry and a favorite destination for many people. This has led sport and its related leagues to become an important element in developing the brand today. Similarly, the nature of sport itself has become an effective ground on the brand development (26). Kirkpatrick et al. (2018) as well as Schneider and Bristow (2007) suggested that sport has become an important and essential industry in the world and it can absorb all people in every situation. This issue can also have an impact on the success of sports concerning brand issues $(27,19)$. Furthermore, 
the growing expansion of sport in the society has contributed to the impact of sport on all aspects of societies. According to $\mathrm{De} \mathrm{Mel}$ and Boccardo (2014), sport has profound effects on all aspects of the world (14).

The sheer number of sporty attractions as well as the great benefits of sports or playing sports has great impacts on people every day. Further, the great potential of sport has prompted many companies and business organizations to select sport as an important arena in their business activities $(14,30,31)$. Consequently, the nature of sport has caused brand issues to develop well in sport $(32,33)$. Nowadays, all sports fields, including basketball, have been able to use the nature of sport as a strong ground for brand empowerment. Therefore, the nature of sport has been able to be well represented as an effective factor in the branding of the Iranian Basketball League. Thus, important factors such as the sports industry, the structure and organization of sport, exclusiveness of sport, and liveliness of the event can be effective in designing, implementing, and improving the brand of the Iran basketball league.

\section{CONCLUSION}

This study indicated that identification of barriers and facilitators of the Basketball League branding depends on identifying and analyzing the internal factors in this league. Paying attention to these factors makes it possible to take meaningful measures in the brand management. Factors such as the management of legal and international affairs, the conditions of players, the particular audience of basketball, and its nature were identified as appropriate strategies for improving branding in the Basketball League. Accordingly, plans to promote brand should be developed within the framework of these strategies. According to the results, it is expected that identification of internal branding factors and challenges of the Iranian Basketball League will lead to the promotion of clubs, brand, basketball league, events, and federation. Further, in this regard, it is necessary to identify the current status of the brand of Iranian Basketball League and resolve the internal issues using existing capabilities.

\section{APPLICABLE REMARKS}

- Nowadays, all sports fields, including basketball, are using the nature of sport as a strong ground for brand improvement. Therefore, the nature of the sport has been well represented as an effective factor in the Iranian Basketball League branding. The main factors such as sports industry, structure and organization of sport, the exclusiveness of sport, and liveliness of the event can be effective in designing, implementing, and improving the Iran Basketball League branding.

- Factors such as the management of legal and international affairs, conditions of players, a particular audience of the sport, and its nature were identified as the strategies for improving basketball league branding. Therefore, brand promotion plans should be developed within the framework of these strategies.

\section{REFERENCES}

1. Chattopadhyay T, Narayan Dutta R, Sivani S. Media mix elements affecting brand equity: A study of the Indian passenger car market. IIMB Manag Rev. 2010; 22(4): 173-185. https://doi.org/10.1016/j.iimb.2010.10.006 [DOI:10.1016/j.iimb.2010.09.001]

2. Bauer H, Stokburger-Sauer E, Exler S. Brand Image and Fan Loyalty in Professional Team Sport: A Refined Model and Empirical Assessment. J Sport Manag. 2008; 22, 205-226. [DOI:10.1123/jsm.22.2.205]

3. Aaker DA, Joachim E. Brand LeaderShip. New York: Free Press Business. 2000 [PMID]

4. Khosravi M, Askari F. Apostolopoulou A Barriers \& Sub-barriers to the Entry of Iranian Football Premier League Clubs into the Stock Exchange. Inter J Hum Cul Stud. 2016; 3(1): 675-691.

5. Apostolopoulou A. Brand extensions by U.S. professional sport teams: Motivations and keys to success. Sport Marke Quar. 2002; 11, 205-214.

6. Doherty A, Murray M. The strategic sponsorship process in a non-profit sport organization. Sport Marke Quar. 2007; 16(1): 45-59 
7. Bodet G, Chanavat N. Building global football brand equity: lessons from the Chinese market. Asi paci J Mark Log, 2010; 22(1): p. $55-66$.

8. Khodaparast S, Hossein Razavi M, Rezaee Soufi M, Safania AM. Evaluating the Components of Marketing Mix (7Ps) of Iran's Volleyball Super League. Ann Appl Sport Sci, 2016; 4(3):35-40. [DOI:10.18869/acadpub.aassjournal.4.3.35]

9. www.iribf.ir/History.asp. (In Farsi).

10. Gladen JM. Developing and Understonding of of Brand Associationin Team Sport. J Spo Manag, 2002; 16: 54-81. [DOI:10.1123/jsm.16.1.54]

11. Al-Salih R, Hartman G. The case Allsvenskan-Brand building within smaller teams. Manag Rev, 2013; 38(2): $102-120$.

12. Corbin J, Strasuss A. Basics of Qualitative Research: Techniques and Procedures for Developing Grounded Theory. SAGE Publications Inc. 2008. [DOI:10.4135/9781452230153]

13. Howard-Payne L. Glaser or Strauss? Considerations for selecting a grounded theory study. Sou Afri J Psych. 2015; 46(1): 50-62. [DOI:10.1177/0081246315593071]

14. De Mel S, Boccardo A. Social Interactions as Brand Benefits: A Sport Marketing Approach. Wor J Soc Sci, 2014; 4(2): 30-46.

15. Tilman B, Lijmbach A. Exploring the reasons why consumers follow a sports brand on social media and the impact this has on brand commitment. Erasmus University Rotterdam. 2012.

16. Tsordiaa Ch, Papadimitrioua D, Parganas P. The influence of sport sponsorship on brand equity and purchase behavior. J Stra Mark, 2018; 26(1): 85-105. [DOI:10.1080/0965254X.2017.1374299]

17. Cheng L. An evaluation of the infuence of experiential marketing on spectators' behaviour in the Taiwanese professional baseball league. A Doctoral Thesis inLoughborough University. 2014.

18. Tong X, Hawley JM. Measuring customer-based brand equity: empirical evidence from the sportswear market in China. J Prod Brand Manag, 2009; 18(4): 262-271. [DOI:10.1108/10610420910972783]

19. Schneider KC, Bristow DN. correlates of brand loyalty in the service sector: the case of a "new" team. Mark Manag J. 2007; 17(2): 56-66.

20. Rasouli M, Fazel Bakhsheshi M, Zareian H. Brand Positioning of the Sport Sciences Research Institution of Iran using Perceptual Mapping Technique. Ann Appl Sport Sci. 2018; 6 (1): 103-113. [DOI:10.29252/aassjournal.6.1.103]

21. Sajjadi SN, Tarighi R, Abedlati M. Prioritizing the Factors Affecting Brand Equity of Popular Football Clubs in Iran. Ann Appl Sport Sci, 2017; 5 (3): 87-93. [DOI:10.29252/acadpub.aassjournal.5.3.87]

22. Keshtidar M, Shajie K, Ebrahimian Besharat M, Yousefi M. Structural Model of the Role of Brand Trust on Brand Identity through the Mediating Role of Brand Love among Fans of Futsal Premier League Clubs in Iran. Ann. Appl. Sport Sci. 2018; 6 (1) :65-74. [DOI:10.29252/aassjournal.6.1.65]

23. Schyvinck C, Willem A. A typology of cause-related marketing approaches in European professional basketball. Sport Manag Rev. 2018, 21(4): 347-362 [DOI:10.1016/j.smr.2017.08.006]

24. Jesyca Salgado-Barandela J, Ángel Barajas A, Sánchez-Fernández P. Determinants of the spending of sporting tourists: The case of attendees at professional basketball. Europ Res Manag Busi Eco. 2018, 24(3): 168-176. [DOI:10.1016/j.iedeen.2018.05.001]

25. Zambom-Ferraresi F, Rios Fernando V, Lera-López F. Determinants of sport performance in European football: What can we learn from the data? Deci Sup Sys. 2018, 114: 18-28. [DOI:10.1016/j.dss.2018.08.006]

26. Rasooli, M. Model designed of Strategic Brand Management for Premier League football clubs. Research project, Sport Science Research Institute . 2014. (Project in Farsi).

27. Kirkpatrick N, Pederson J, White D. Sport business and marketing collaboration in higher education J Hosp, Leis, Sport Tour Edu. 2018, 22: 7-13.

28. Wang RT, Zhang JJ, Tsuji Y. Examining fan motives and loyalty for the chinese professional baseball league of Taiwan. Spo Manag Rev, 2011; 14(4): 347-360. [DOI:10.1016/j.smr.2010.12.001]

29. Leach S, Szymanski S. Making money out of football. Scot J Poli Econ. 2015; 62(1):25-50 [DOI:10.1111/sjpe.12065]

30. Tapiwanashe L. The use of sport sponsorship as a brand equity building tool by Zimbabwean companies. Glo $\mathrm{J}$ Comme Manag Pers. 2015; 4(4):19-25

31. Cosmas JD, Guveya A. The Impact of Sports Sponsorship on Brand Equity Dimensions: A Case of Castle Lager Brand in Zimbabwe. Inter J Sci Res (IJSR). 2016; 5(5): 1958-63. [DOI:10.21275/v5i5.NOV163837]

32. Pouder RW, Clark D, Fenich G. An exploratory study of how destination marketing organizations pursue the sports tourism market. J Desti Market Manage. 2018, 9:184-193. [DOI:10.1016/j.jdmm.2018.01.005]

33. Baker B, McDonald H, Funk C. The uniqueness of sport: Testing against marketing's empirical laws. Sport Manage Rev. 2016, 19(4): 378-390. [DOI:10.1016/j.smr.2016.02.002] 